\title{
Effect of different regimens of early malnutrition on behavioural development and adult avoidance learning in Swiss white mice
}

\author{
By MAUREEN BUSH AND P. D. LEATHWOOD \\ Research Department, Nestlé Products Technical Assistance, \\ La Tour-de-Peilz, Switzerland \\ (Received 22 April $1974-$ Accepted 12 August 1974)
}

\begin{abstract}
I. The effects of perinatal malnutrition on behavioural development and adult shuttle-box avoidance performance were studied in Swiss white mice.

2. Mice were malnourished $(a)$ from the 7 th day of gestation until birth, $(b)$ from birth until weaning, or $(c)$ during both gestation and the sucking period.

3. Pups born of protein-restricted mothers had reduced birth weights, retarded development and poor adult avoidance performance, even if reared from birth by well-nourished mothers.

4. Postnatal malnutrition, induced either by restricting maternal diet or by rearing in large litters, retarded development during the second half of lactation and lowered subsequent adult avoidance performance.
\end{abstract}

Many studies have attempted to identify the effects of early nutritional deprivation on experimental animals. Lát, Widdowson \& McCance (I960) showed that physical maturation and the appearance of certain reflexes in the rat were delayed by nutritional deprivation provoked by rearing rats in large litters. Similar results may be observed if the mother's food intake is restricted (Smart \& Dobbing, 1971 $a$ ) or if she is fed on a low-protein diet (Cowley \& Griesel, 1966). Simonson, Sherwin, Anilane, Yu \& Chow (1968) found that restriction of maternal diet during pregnancy delayed physical and behavioural development of the offspring, even when the young were adopted at birth by well-nourished mothers. However, Smart $\&$ Dobbing (197 $b$ ) found that although restriction during gestation produced significant physical stunting at birth, effects on reflex ontogeny were negligible.

The long-lasting effects of early nutritional deprivation in rodents include physical stunting (Widdowson \& McCance, I963), changes in food-related behaviour (Seitz, 1954) and more intense reactions to aversive situations (Levitsky \& Barnes, 1970). Mice undernourished by rearing in large litters show marked reductions in shuttle-box avoidance-learning ability (Leathwood, Bush, Berent \& Mauron, 1974). This large litter design for inducing early malnutrition has several limitations: the pups are malnourished only during the sucking period and, probably more important, account must be taken of effects of litter size, per se, on adult behaviour.

The present experiments examine how different regimens of early malnutrition influence behavioural and physical development and adult avoidance performance of Swiss white mice. During the developmental study pups were handled every day from birth to $2 \mathrm{I} \mathrm{d}$ of age. As early handling can influence adult behaviour (Levine \& 
Table I. Composition ( $\mathrm{g} / \mathrm{kg}$ ) of the low-protein, casein diets given to mice

\begin{tabular}{|c|c|c|}
\hline Casein & 50 & 100 \\
\hline Agar & 20 & 20 \\
\hline Salt mixture* & 30 & $3^{\circ}$ \\
\hline Maize starch & $55^{\circ}$ & 500 \\
\hline Sucrose & 250 & $25^{\circ}$ \\
\hline Olive oil & 100 & 100 \\
\hline DL-methionine & I & - \\
\hline \multicolumn{3}{|c|}{ Vitamins (ml/animal per $\mathrm{d}) \dagger$} \\
\hline Fat-soluble & $0 . I$ & 0.1 \\
\hline Water-soluble & $x \cdot 0$ & $\mathrm{I} \cdot \mathrm{O}$ \\
\hline
\end{tabular}

Mullins, I966), the avoidance performance of these previously malnourished, handled animals was compared with the performance of mice subjected to similar regimens of malnutrition but left undisturbed until weaning.

\section{EXPERIMENTAL}

Mice were drawn from a colony of randomly bred, Swiss white mice maintained in this laboratory. They were kept on a $12 \mathrm{~h}$ light- $\mathrm{I} 2 \mathrm{~h}$ dark cycle commencing at o6.0o hours. Nulliparous females aged $2 \cdot 5^{-3}$ months were housed four/cage with one male/cage and the day of mating was determined by the presence of a vaginal plug. From the 7 th day of gestation, one group of mice was given a diet with $50 \mathrm{~g}$ casein $/ \mathrm{kg}$ until parturition and a diet containing $100 \mathrm{~g}$ casein $/ \mathrm{kg}$ during lactation. The others received a pelleted stock diet (Nafag S.A., Gossau, Switzerland) with 200 g protein $/ \mathrm{kg}$ throughout gestation and lactation. The pregnant mice were randomly assigned to these different treatments. In a preliminary experiment one control group was given a diet with $200 \mathrm{~g}$ casein $/ \mathrm{kg}$ and another the pelleted stock diet with $200 \mathrm{~g}$ protein $/ \mathrm{kg}$. Growth, development and adult avoidance performance of the offspring were virtually identical.

The low-protein diets had compositions as shown in Table $\mathrm{I}$.

The food was prepared as a pudding (Mauron \& Mottu, I962) and supplied ad lib. to the mice so that they ate to appetite. Pups also had access to the diet and began to eat it at $\mathrm{I}_{5}-\mathrm{I} 7 \mathrm{~d}$ of age.

At birth all pups were sexed and cross-fostered into litters of five pups per mother giving the following experimental groups: $(a)$ pups born to and reared by wellnourished mothers $\left(\mathrm{G}^{+} \mathrm{L}^{+}\right) ;(b)$ pups born to well-nourished mothers but reared by malnourished mothers $\left(\mathrm{G}^{+} \mathrm{L}^{-}\right) ;(c)$ pups born to malnourished mothers and reared by well-nourished mothers $\left(\mathrm{G}^{-} \mathrm{L}^{+}\right)$; $(d)$ pups born to and reared by malnourished mothers $\left(\mathrm{G}^{-} \mathrm{L}^{-}\right)$; $(e)$ (for comparison with the large-litter model for inducing early malnutrition) pups born to and reared by well-nourished mothers but with twenty pups in each litter (20's).

Throughout this paper we have used a shorthand notation adapted from that of 
Smart \& Dobbing ( $\mathrm{r} 97 \mathrm{r} a, b)$. Thus $\mathrm{G}^{+}$denotes adequate nutrition during gestation; $\mathrm{G}^{-}$, protein restriction during gestation; $\mathrm{L}^{+}$, adequate nutrition throughout lactation and $\mathrm{L}^{-}$, protein restriction during lactation.

In a pilot study we found that more deaths occurred in the $\mathrm{G}^{+} \mathrm{L}^{-}$and $\mathrm{G}^{-} \mathrm{L}^{-}$ groups; therefore, in the complete development experiment a total of twenty-three litters was studied (four $\mathrm{G}^{+} \mathrm{L}^{+}$, five $\mathrm{G}^{-} \mathrm{L}^{+}$, six $\mathrm{G}^{+} \mathrm{L}^{-}$, six $\mathrm{G}^{-} \mathrm{L}^{-}$and two $20^{\prime}$ ). During the course of this study these animals were handled every day throughout lactation. In anticipation of deaths in the experimental groups, extra litters were set up and dead pups replaced as necessary. As each new pup was added to an experimental group it was marked by injection of indian ink under the skin of a hind paw so that it could be eliminated from subsequent statistical analyses. Those that were not so needed, six litters of $\mathrm{G}^{+} \mathrm{L}^{+}$, six $\mathrm{G}^{+} \mathrm{L}^{-}$and three $20^{\text {'s, }}$, were left undisturbed except when the bedding was changed each week. All litters were weaned onto stock diet at 3 weeks of age. Survival rates were recorded, males were separated from females and housed eight/cage in $0.25 \times 0.20 \times 0.14 \mathrm{~m}$ Macrolon cages until the end of the experiment. Shuttle-box avoidance learning began at 8 weeks old and continued until the IIth week. The following week five mice from each group were killed and regional brain weights and DNA content determined.

\section{Physical and behavioural development}

Growth. It was difficult to measure birth weight with live pups because most mothers suckled their pups soon after birth, and when each newborn litter was found, some pups had stomachs full of milk whilst others were empty. In order to obtain more accurate estimates of birth weight eight $\mathrm{G}^{+}$and nine $\mathrm{G}^{-}$litters were killed at birth and their stomach contents removed before weighing. Also included in this repetition were eight litters whose mothers had been fed half the normal daily amount of stock diet from the $7^{\text {th }}$ day of gestation.

Reflexes. The mice were examined daily for eye-opening, ear-unfolding, the appearance of fur and development of the auditory startle response. Behavioural development of pups was studied on alternate days until the 2ist day. Every pup was tested once for a given response each day. We monitored the development of the following reflexes: grasping, righting, crawling, fore-limb placing response, free-fall righting, and auditory startle response. The testing procedure was exactly as described by Fox (1965), but the strength of the response was graded on a 0-4 scale: 0 no response, I weak response, 2 moderate response, 3 strong response and 4 adult-like response.

Avoidance learning. The apparatus was essentially as described by Bovet, BovetNitti \& Oliverio (1968). The shuttle-box consisted of a white rectangular Plexiglass box $0.4 \times 0.1 \mathrm{~m}$ divided into two equal compartments and connected by a small opening $(30 \times 30 \mathrm{~mm})$. The floor was a tilting platform of stainless-steel rods spaced $4 \mathrm{~mm}$ apart. In each trial the conditioning stimuli, light (from a $10 \mathrm{~W}$ bulb) and sound (approximately $5 \mathrm{kHz}, 60 \mathrm{~dB}$ ) preceded by $5 \mathrm{~s}$ the unconditioned stimulus (continuous $30 \mathrm{~V}$ a.c. shock through the grid floor scrambled through a silicon rectifier) and overlapped with it for $2 \mathrm{~s}$. A resistance of $3 \circ \mathrm{k} \Omega$ was mounted in line with the shock circuit of each cage to reduce fluctuation in current flow due to changes in 
Table 2. Effect of maternal diet on litter size and body-weights (minus stomach contents) of newborn mice

\begin{tabular}{|c|c|c|c|c|c|c|}
\hline \multirow[b]{2}{*}{ Mothers' diet } & \multirow{2}{*}{$\begin{array}{l}\text { No. of } \\
\text { litters }\end{array}$} & \multicolumn{2}{|c|}{ Litter size } & \multirow{2}{*}{$\begin{array}{l}\text { Total no. } \\
\text { of pups }\end{array}$} & \multicolumn{2}{|c|}{ Birth weight } \\
\hline & & Mean & SE & & Mean & SE \\
\hline Stock diet, ad lib. & 8 & $12 \cdot 5$ & 0.98 & roo & $1 \cdot 54$ & 0.013 \\
\hline ad lib. & 9 & $6 \cdot 0$ & $0.7 \mathrm{I}$ & 54 & 0.84 & 0.013 \\
\hline intake & 8 & $12 \cdot 6$ & 0.95 & IOI & $x \cdot 42$ & 0.010 \\
\hline
\end{tabular}

posture and contact of the animal with the grid floor and to limit current flow to I. $\mathrm{mA}$. The shock was switched off at initiation of the following trial. Mice avoided the shock by running into the adjacent compartment within $5 \mathrm{~s}$ of the onset of light and sound. Passage of the mouse from one side of the box to the other was recorded by a micro-switch tripped by movement of the tilting floor. All animals were given fourteen daily sessions of fifty trials each with an interval of $30 \mathrm{~s}$ between each trial.

\section{Dissection and DNA determinations}

At $80 \mathrm{~d}$ of age, five mice from each group were killed, their brains separated from the spinal cord at the foramen magnum and divided into forebrain, brain stem and cerebellum. The forebrain was separated from the brain stem just anterior to the corpora quadrigemina. Each region was weighed and stored frozen at $-20^{\circ}$ until required for DNA analysis. DNA was extracted and assayed as described by Margolis (1969).

\section{RESULTS}

Table 2 shows that the low-protein diet produced severe reductions in birth weight $(30-40 \%)$, whilst restricted intake of stock diet $(50 \%$ of control intake) produced only an $8 \%$ reduction. With more severe restriction of stock diet it was not possible to obtain an accurate estimate of the reduction because the mothers ate their young shortly after birth.

\section{Development}

All $\mathrm{G}^{+} \mathrm{L}^{+}$and $\mathrm{G}^{+} \mathrm{L}^{--}$pups survived to adulthood but there were some deaths in the other groups. Most of these occurred within $24 \mathrm{~h}$ of cross-fostering, apparently because the pups were rejected by their foster-mother. Eleven $\mathrm{G}^{-} \mathrm{L}^{+}$and six $\mathrm{G}^{-} \mathrm{L}^{-}$ pups died in this manner, while two pups from the litters containing twenty pups died within $7 \mathrm{~d}$ of birth. Results for physical and behavioural development were obtained for all mice surviving at each day's observation.

The prenatally deprived pups, if nourished by adequately-fed mothers $\left(\mathrm{G}^{-} \mathrm{L}^{+}\right)$, grew faster than the $\mathrm{G}^{+} \mathrm{L}^{-}$and $20^{\prime}$ 's (Fig. I) so that, at weaning, they weighed $10^{\circ} 3 \pm$ 0.2 (SEM) g compared with $8.3 \pm 0.06 \mathrm{~g}$ for the $\mathrm{G}^{+} \mathrm{L}^{-}$mice and $6.5 \pm 0.025 \mathrm{~g}$ for the $20^{\prime}$ 's. Although the $\mathrm{G}^{-} \mathrm{L}^{+}$mice were heavier than $\mathrm{G}^{+} \mathrm{L}^{-}$and $20^{\text {'s }}$ at weaning, as adults they showed more marked weight reductions. This delayed consequence of prenatal 


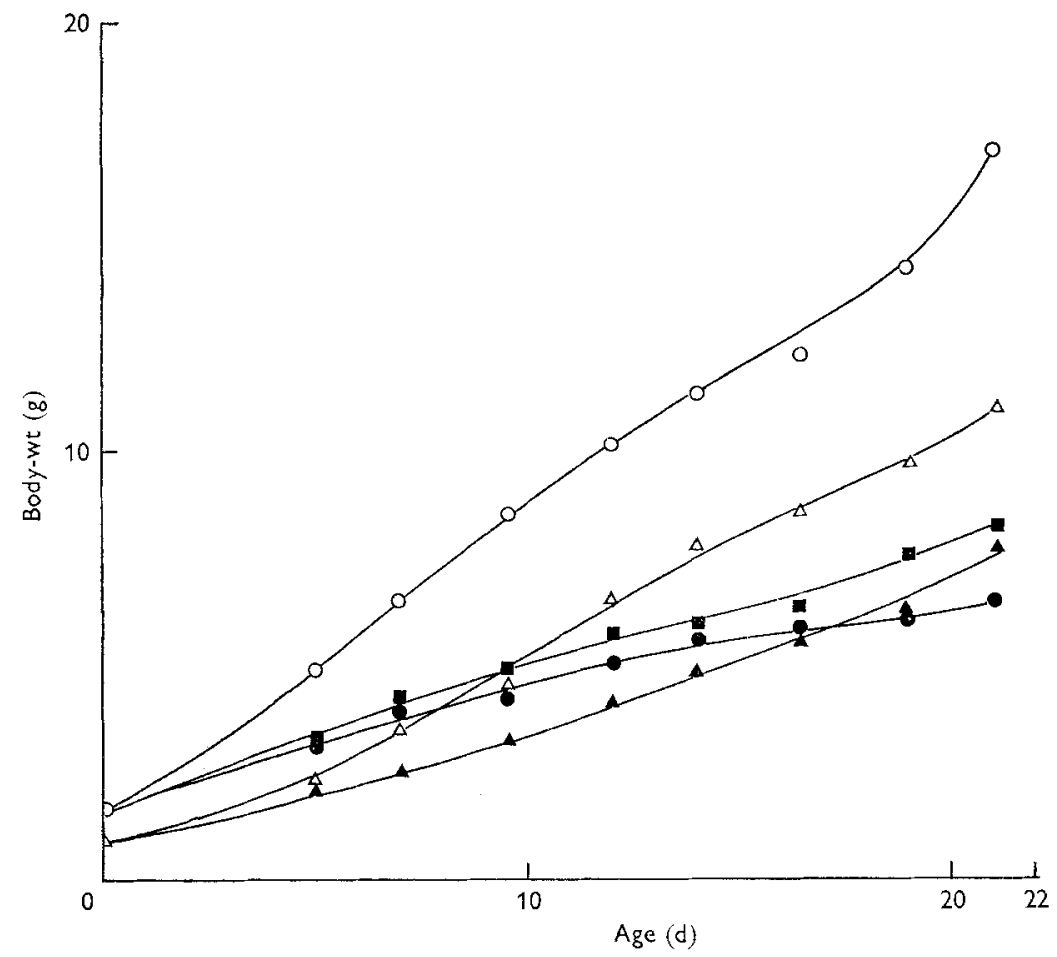

Fig. I. The effects of different pre- and postnatal feeding regimens on the body-weights of mouse pups during sucking. - $\mathrm{O}-\mathrm{O}-, \mathrm{G}^{+} \mathrm{L}^{+}$(pups born to and reared by well-nourished mothers); - - -, $\mathrm{G}^{+} \mathrm{L}^{-}$(pups born to well-nourished mothers but reared by malnourished mothers); $-\triangle-\triangle-, \mathrm{G}^{-} \mathrm{L}^{+}$(pups born to malnourished mothers but reared by well-nourished mothers); - $-\mathbf{A}-, \mathrm{GG}^{-} \mathrm{L}^{-}$(pups born to and reared by malnourished mothers); $\longrightarrow-$ 20's (pups born to and reared by well-nourished mothers but with twenty pups in each litter).

nutritional deprivation has already been found in rats by Blackwell, Blackwell, Yu, Weng \& Chow (1969).

The ages at which different physical features developed are shown in Fig. 2. Ear opening, the appearance of fur and opening of the eyes were all retarded in the prenatally deprived mice even when they were reared by well-nourished mothers. By ro d of age the postnatally undernourished groups ( $\mathrm{G}^{+} \mathrm{L}^{-}$and $20^{\prime}$ 's) began to fall behind the controls. None of these physical features matured later than ${ }_{5} \mathrm{~d}$ so it was not possible to evaluate the late ( $15^{-2} \mathrm{I} d$ ) effects of postnatal deprivation.

The development of reflex behaviour followed a similar pattern. Reflexes that developed early in the control $\left(\mathrm{G}^{+} \mathrm{L}^{+}\right)$mice were delayed by prenatal nutritional deprivation whereas postnatal deprivation due to rearing in large litters or caused by sucking from malnourished mothers, only began to take effect after 8-io d (Fig. 3)

As the development of most characteristics was rated for each animal on a $0-4$ scale, it was possible to analyse the results using the one-tailed, Kolmogorov-Smirnov two-sample test (Siegel, I956). Table 3 shows the ten possible comparisons between the five experimental groups, with the day of statistical testing indicated for each physical or behavioural feature. Both prenatally undernourished groups $\left(\mathrm{G}^{-} \mathrm{L}^{+}\right.$and 


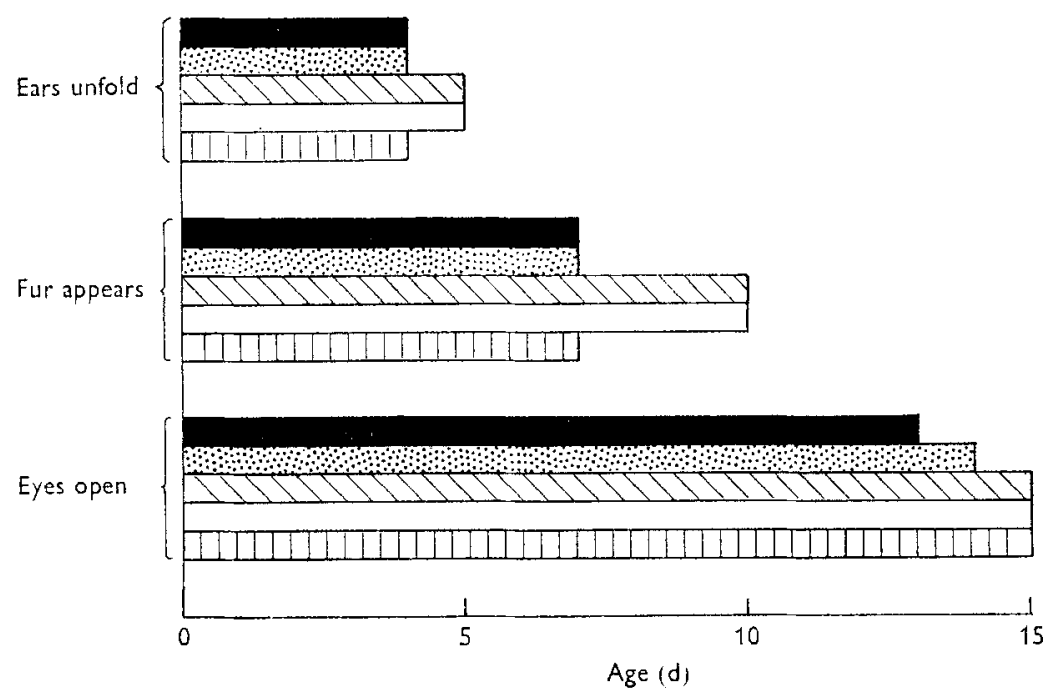

Fig. 2. Effect of different pre- and postnatal feeding regimens on the mean age of mouse pups at maturation of three physical features: ear unfolding, appearance of fur, eye opening. $\mathbf{0}$,

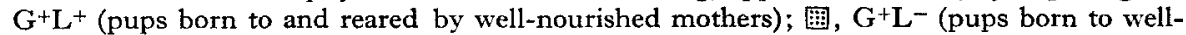
nourished mothers but reared by malnourished mothers); $\mathbb{Q}, \mathrm{G}-\mathrm{L}^{+}$(pups born to malnourished mothers but reared by well-nourished mothers); $\square, G^{-} L^{-}$(pups born to and reared by malnourished mothers); U1, 20's (pups born to and reared by well-nourished mothers, but with twenty pups in each litter).

$\mathrm{G}^{-} \mathrm{L}^{-}$) were significantly retarded in every characteristic when compared with the control $\left(\mathrm{G}^{+} \mathrm{L}^{+}\right)$group and in almost all characteristics when compared with the $\mathrm{G}^{+} \mathrm{L}^{-}$mice. At 3 and $5 \mathrm{~d}$ the $\mathrm{G}^{-} \mathrm{L}^{+}$mice were significantly behind the $20^{\prime}$ 's but had overtaken them by $14 \mathrm{~d}$. Postnatal undernutrition significantly retarded development in pups from large litters from the 9 th day (column 4 ) while the $\mathrm{G}^{+} \mathrm{L}^{-}$- groups were not significantly affected until $\mathrm{I}_{4} \mathrm{~d}$ old (column $\mathrm{r}$ ).

\section{Avoidance learning}

Conditioned avoidance performance in the shuttle-box was studied when the mice were 8-rI weeks old. Learning curves are shown in Fig. 4 and the results are summarized in Table 4.

All nutritionally deprived groups achieved significantly fewer successful avoidances than the controls $\left(\mathrm{G}^{+} \mathrm{L}^{+}\right)$, although only the 20's were significantly worse than $\mathrm{G}^{+} \mathrm{L}^{-}$mice $(t 2 \cdot 3 \mathrm{I}, P<0 \cdot 05)$.

\section{Effects of early handling}

The previous behavioural results were obtained using mice which had been handled in early life, during the development studies. To test for the possibility of an interaction between the effects of early handling and early nutritional deprivation, avoidance performance and body-weights of handled mice were compared with those of mice subjected to early nutritional deprivation but otherwise left undisturbed until weaning. 


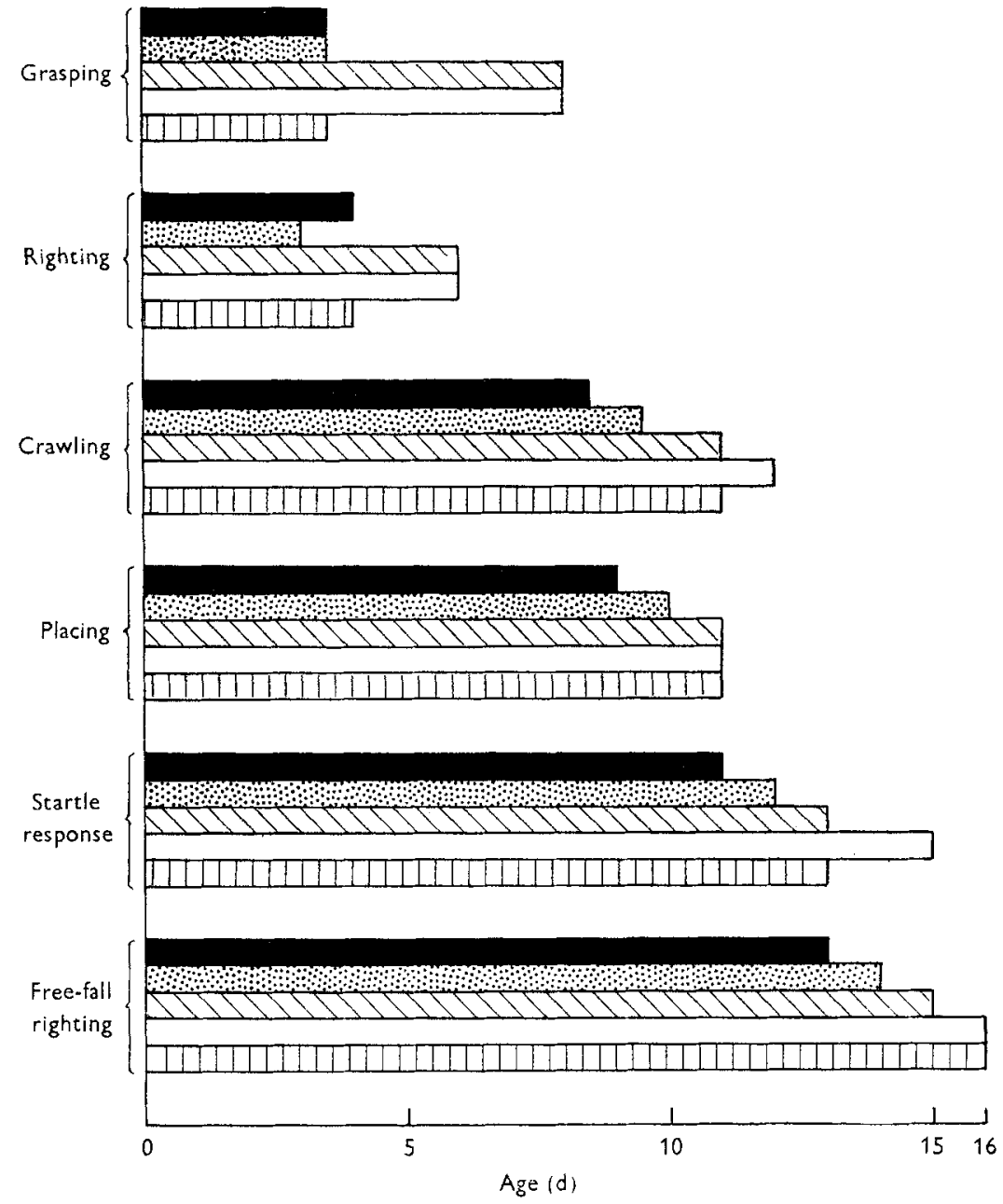

Fig. 3. The effect of different pre- and postnatal feeding regimens on the age of mouse pups when they achieved a mean group score of 2 (on a $0-4$ development scale) for six behavioural reflexes: grasping, righting, crawling, placing, startle response and free-fall righting. $\mathbf{m}, \mathbf{G}^{+} \mathbf{L}^{+}$

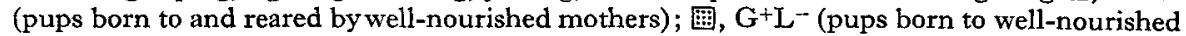
mothers but reared by malnourished mothers); $\mathbb{G} \mathrm{G}^{-} \mathrm{L}^{+}$(pups born to malnourished mothers but reared by well-nourished mothers); $\square, \mathrm{G}^{-} \mathrm{L}^{-}$(pups born to and reared by malnourished mothers); TI, 2o's (pups born to and reared by well-nourished mothers, but with twenty pups in each litter).

Early handling was associated with significantly higher body-weights in two of three comparisons (Table 5). A two-way analysis of variance with handled mice $v$. non-handled mice as one factor, and with early nutritional status as the other, showed that body-weight was significantly affected by early nutritional status $(P<0 \circ$ or $)$ but there was no interaction, suggesting that early handling did not differentially influence control and malnourished groups.

The previously handled mice performed the avoidance task slightly, but not significantly, better than their non-handled counterparts (Table 6). Analysis of 
Table 3. The significance of differences in maturation of physical features and reflex behaviour between groups* of mice subjected to different pre- and postnatal feeding regimens

\begin{tabular}{|c|c|c|c|c|c|c|c|c|c|c|c|}
\hline & & & Sigr & aificanc & of dif & fference & c $(P) \mathrm{f}$ & or: & & & \\
\hline & $\mathrm{G}^{+} \mathrm{L}^{+}$ & $\mathrm{G}^{+} \mathrm{L}^{+}$ & $\mathrm{G}^{+} \mathrm{L}^{+}$ & $\mathrm{G}^{+} \mathrm{L}^{+}+$ & $\mathrm{G}^{+} \mathrm{L}^{-}$ & $\mathrm{G}^{+} \mathrm{L}^{-}$ & $\mathrm{G}^{+} \mathrm{L}^{-}$ & $\mathrm{G}^{-} \mathrm{L}^{++}$ & $20 ' \mathrm{~s}$ & $20^{\prime} \mathrm{s}$ & $f^{\circ}$ \\
\hline & $\stackrel{>}{\mathrm{G}+\mathrm{L}^{-}}$ & $\underset{\mathrm{G}-\mathrm{L}^{+}}{>}$ & $\stackrel{\mathrm{G}^{-} \mathrm{L}^{-}}{>}$ & $\underset{20 ' s}{>}$ & $\stackrel{\overrightarrow{G^{-}}}{>+}$ & $\stackrel{>}{\mathrm{G}^{-\mathrm{L}^{-}}}$ & $\begin{array}{c}> \\
20 ' s\end{array}$ & $\underset{\mathrm{G}^{-} \mathrm{L}^{-}}{>}$ & $\underset{\mathrm{G}^{-} \mathrm{L}^{+}}{>}$ & $\stackrel{>}{\mathrm{G}^{-} \mathrm{L}^{-}}$ & testing \\
\hline Ears unfolding & - & 0.01 & 0.01 & - & 0.01 & 0.01 & - & - & 0.05 & 0.01 & 3 \\
\hline Fur appearance & - & $0.0 I$ & 0.01 & - & 0.01 & 0.01 & - & - & 0.01 & $0.0 \mathrm{I}$ & 5 \\
\hline Eye opening & - & 0.01 & 0.01 & 0.01 & 0.01 & 0.01 & 0.05 & - & - & - & 14 \\
\hline Grasping & - & 0.01 & 0.01 & - & 0.01 & 0.01 & - & - & $0.0 \mathrm{I}$ & $0.0 \mathrm{I}$ & 3 \\
\hline Righting & - & 0.05 & 0.05 & - & 0.01 & 0.01 & 一 & - & - & - & 5 \\
\hline Auditory startle & - & 0.01 & 0.01 & 0.01 & 0.05 & 0.01 & 0.01 & - & $\ldots$ & - & I 2 \\
\hline Crawling & - & 0.01 & 0.01 & 0.01 & 0.01 & 0.05 & 0.05 & - & - & - & 9 \\
\hline Vibrissae placing & - & $0.0 \mathrm{I}$ & 0.01 & 0.01 & $0.0 \mathrm{I}$ & 0.01 & 0.01 & - & - & - & 12 \\
\hline Free-fall righting & 0.01 & 0.05 & 0.01 & 0.01 & $\ldots$ & 0.01 & 0.01 & 0.01 & 0.011 & - & 14 \\
\hline
\end{tabular}

$\mathrm{G}^{+}$,well-nourished during gestation; $\mathrm{G}^{-}$, malnourished during gestation; $\mathrm{L}^{+}$, well-nourished during lactation; L-, malnourished during lactation; 20's, well-nourished, twenty pups/litter,

* For details, see p. 374 .

+ Difference expressed in terms of the retardation of the 2 nd group relative to the ist.

This difference was opposite to that indicated i.e. the ist group was retarded relative to the 2 nd. During the Ist few days of life, development of the $\mathrm{G}^{-} \mathbf{L}^{+}$mice was retarded in comparison with the 20 's, but they grew rapidly and overtook the 20 's by $14 \mathrm{~d}$ of age.

variance showed that effects due to early nutritional status were significant $(P<0.0$ I $)$ but there were no significant handling effects or interaction.

\section{Regional brain weights and $D N A$ content}

Prenatal nutritional deprivation had more effect on forebrain weight than did deprivation during sucking (Table 7). Similar results have been reported by Smart, Dobbing, Adlard, Lynch \& Sands (1973). Malnutrition during sucking had more effect on cerebellum weight than on forebrain weight. Both postnatally malnourished groups (20's and $\mathrm{G}^{+} \mathrm{L}^{-}$) had similar patterns of brain- and body-weight reductions although the 20's were more severely affected. Regional reductions in brain DNA content were similar to those for wet weight (Table 8). Again, the forebrain DNA (cell number) was most affected by prenatal deprivation while the cerebellum DNA content was equally diminished in $\mathrm{G}^{-} \mathrm{L}^{+}$and $\mathrm{G}^{+} \mathrm{L}^{-}$groups (although the $\mathrm{G}^{-} \mathrm{L}^{+}$ mice were well-nourished and were growing rapidly throughout the cerebellum growth spurt). Winick (1970) and Smart et al. (1973) found in rats that undernutrition throughout gestation and lactation produced a greater reduction in cell number than in either of these periods alone. In mice this 'synergistic' effect was not found with our technique of nutritional deprivation.

\section{DISCUSSION}

The different pre- and postnatal feeding regimens and the consequent malnutrition had markedly different effects on birth weight, development and adult behaviour. It 


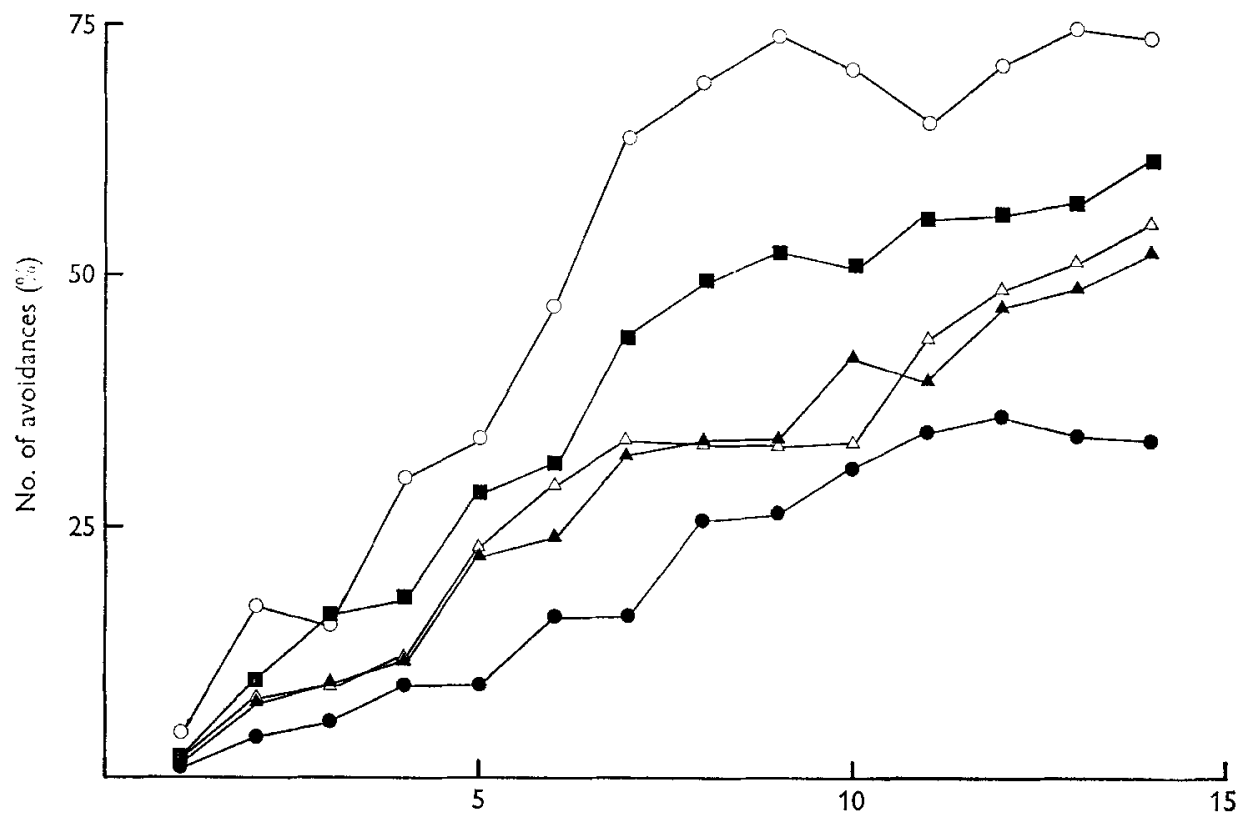

No. of sessions

Fig. 4. The effect of different pre- and postnatal feeding regimens on the avoidance-conditioning performance of adult mice (8-I I weeks old). $-\mathrm{O}-\mathrm{O}-, \mathrm{G}^{+} \mathrm{L}^{+}$(born to and reared by wellnourished mothers); - $-\square-, \mathrm{G}^{+} \mathrm{L}^{-}$(born to well-nourished mothers and reared by malnourished mothers); $-\triangle-\triangle-, G^{-} L^{+}$(born to mainourished mothers and reared by well-nourished); - $\mathbf{A}-, \mathbf{G}^{-} \mathbf{L}^{-}$(born to and reared by malnourished mothers); - (born to and reared by well-nourished mothers, but with twenty pups in each litter).

Table 4. Effects of different pre- and postnatal feeding regimens on avoidance performance of mice at 8-I I weeks of age

\begin{tabular}{|c|c|c|c|c|c|}
\hline \multirow[b]{2}{*}{ Group* } & \multicolumn{4}{|c|}{ No. of successful avoidances $(\%)$} & \multirow{2}{*}{$\begin{array}{l}\text { Significance of } \\
\text { difference } \\
\text { between groups }\end{array}$} \\
\hline & No. of mice & Mean & $\mathrm{SE}$ & $t \dagger$ & \\
\hline & & & & & $P$ \\
\hline $\mathrm{G}^{+} \mathrm{L}^{+}$ & I6 & $50 \cdot 8$ & $3 \cdot 3$ & 一 & - \\
\hline $\mathrm{G}^{+} \mathrm{L}^{-}$ & 22 & $38 \cdot 4$ & $4 \cdot 5$ & $2 \cdot 19$ & $<0.05$ \\
\hline $\mathrm{G}^{-} \mathrm{L}^{+}$ & 12 & $29 \cdot 7$ & 5.8 & $3 \cdot 14$ & $<0.01$ \\
\hline $\mathrm{G}^{-} \mathrm{L}^{-}$ & $2 I$ & $29 \cdot 1$ & $4 \cdot 2$ & 4.02 & $<0.01$ \\
\hline 20 's & I9 & $22 \cdot 7$ & 4.7 & $4 \cdot 88$ & $<0.01$ \\
\hline
\end{tabular}

$\mathrm{G}^{+}$, well-nourished during gestation; $\mathrm{G}^{-}$, malnourished during gestation; $\mathrm{L}^{+}$, well-nourished during lactation; $\mathrm{L}^{-}$, malnourished during lactation; 20's, well-nourished, twenty pups/litter.

* For details, see p. 374 .

$\dagger t$ Values were calculated by comparing each group with the $\mathrm{G}^{+} \mathrm{L}^{+}$mice.

has been suggested (Smart \& Dobbing, I97I $b$ ) that reflex ontogeny is unaffected in prenatally undernourished rats fostered onto well-nourished dams, although Simonson et al. (1968), using a similar model, found significant delays in the appearance of most developmental indices. Our experiments show that in mice, postnatal development is severely retarded by feeding the mother on a low-protein diet during the last 2 weeks 
Table 5. Effects of early handling and different pre- and postnatal feeding regimens on body-weight of mice

\begin{tabular}{|c|c|c|c|c|c|}
\hline \multirow[b]{2}{*}{ Group* } & \multirow[b]{2}{*}{ No. of mice } & \multicolumn{2}{|c|}{$\begin{array}{l}\text { Body-weight } \\
\text { at } 56 \mathrm{~d}(\mathrm{~g})\end{array}$} & \multirow[b]{2}{*}{$t$} & \multirow{2}{*}{$\begin{array}{l}\text { Significance of } \\
\text { difference } \\
\text { between values } \\
\text { for handled } \\
\text { and non- } \\
\text { handled } \\
\text { groups: } \\
P\end{array}$} \\
\hline & & Mean & $\mathrm{SE}$ & & \\
\hline $\begin{array}{l}\mathrm{G}^{+} \mathrm{L}^{+} \\
\text {Handled } \\
\text { Non-handled }\end{array}$ & $\begin{array}{l}17 \\
23\end{array}$ & $\begin{array}{l}40 \cdot 3 \\
39 \cdot 1\end{array}$ & $\begin{array}{l}0.78 \\
0.51\end{array}$ & $r \cdot 25$ & NS \\
\hline $\begin{array}{l}\mathrm{G}^{+} \mathrm{L}^{-} \\
\text {Handled } \\
\text { Non-handled }\end{array}$ & $\begin{array}{l}22 \\
23\end{array}$ & $\begin{array}{l}34 \cdot 8 \\
33 \cdot 4\end{array}$ & $\begin{array}{l}0.49 \\
0.49\end{array}$ & $2 \cdot I Y$ & $<0.05$ \\
\hline $\begin{array}{l}\text { 20's } \\
\text { Handled } \\
\text { Non-handled }\end{array}$ & $\begin{array}{l}19 \\
23\end{array}$ & $\begin{array}{l}33 \cdot 1 \\
30 \cdot 7\end{array}$ & $\begin{array}{l}0.49 \\
0.45\end{array}$ & $3 \cdot 387$ & $<0.01$ \\
\hline
\end{tabular}

NS, not significant; $\mathrm{G}^{+}$, well-nourished during gestation; $\mathrm{L}^{+}$, well-nourished during lactation; $\mathrm{L}^{-}$, malnourished during lactation; 20's, well-nourished, twenty pups/litter.

* For details, see p. 374 .

Table 6. Effects of early handling and different pre- and postnatal feeding regimens on shock-avoidance performance of mice at 8-I I weeks of age

$\left.\begin{array}{lcccc}\text { Group* } & \begin{array}{c}\text { No. of } \\ \text { mice }\end{array} & \begin{array}{c}\text { No. of successful } \\ \text { avoidances (\%) }\end{array} & \text { SE } & t \\ \begin{array}{l}\mathrm{G}^{+} \mathrm{L}^{+} \\ \quad \text { Handled }\end{array} & 16 & 50 \cdot 8 & 3 \cdot 3 & \\ \quad \begin{array}{l}\text { Non-handled } \\ \text { G+L- }\end{array} & 23 & 43 \cdot 7 & 4 \cdot \mathrm{I} & \end{array}\right\} \mathbf{I} \cdot 3 \mathrm{I}$

$\mathrm{G}^{+}$, well-nourished during gestation; $\mathrm{L}^{+}$, well-nourished during lactation; $\mathrm{L}^{-}$, malnourished during lactation; 20's well-nourished, twenty pups/litter.

* For details, see p. 374 .

of gestation. If prenatally malnourished pups $\left(\mathrm{G}^{-}\right)$were less vigorous than controls, it is possible that they would not suck efficiently, and therefore would not benefit immediately from cross-fostering onto well-fed mothers; but in all surviving litters, the pups' stomachs were bloated with milk from the ist day of adoption. None of the pups used in the developmental study were premature but the possibility cannot be ruled out that during the first few days of life the prenatally deprived mice could not metabolize their mother's milk efficiently and so continued to be malnourished postnatally. Even so, a comparison of growth curves of $\mathrm{G}^{-} \mathrm{L}^{+}$and $\mathrm{G}^{-} \mathrm{L}^{-}$mice shows 
Table 7. Effects of different pre- and postnatal feeding regimens on body-weights and wet weights of forebrain and cerebellum of mice at $80 \mathrm{~d}$ of age

(Mean values with their standard errors, where given, for five mice/group)

\begin{tabular}{|c|c|c|c|c|c|}
\hline Groupt & $\mathrm{G}^{+} \mathrm{L}^{+}$ & $\mathbf{G}^{+} \mathbf{L}^{-}$ & $\mathbf{G}^{-\mathbf{L}^{+}}$ & $\mathrm{G}^{-} \mathrm{L}^{-}$ & 20 's \\
\hline \multicolumn{6}{|l|}{ Body-wt } \\
\hline $\begin{array}{l}\text { Relative to } \mathrm{G}^{+} \mathrm{L}+\text { value }(\%) \\
\text { Value different }(t) \text { from } \\
\text { that for group: }\end{array}$ & - & $-x_{5}$ & -24 & -29 & -22 \\
\hline $\begin{array}{l}\mathrm{G}^{+} \mathrm{L}^{+} \\
\mathrm{G}^{+} \mathrm{L}^{-}\end{array}$ & - & $4 \cdot 43^{* * *}$ & $\begin{array}{l}9 \cdot 80^{* * *} \\
2 \cdot 62 *\end{array}$ & $\begin{array}{l}7 \cdot 05^{* *} \\
2 \cdot 8 I^{*}\end{array}$ & $\begin{array}{c}10.52^{* * *} \\
2.02 *\end{array}$ \\
\hline $\mathrm{G}^{-} \mathrm{L}^{+}$ & 一 & - & - & $\mathrm{I} \cdot 05$ & $\mathrm{I} \cdot \mathrm{I}_{4}$ \\
\hline $\mathrm{G}^{-} \mathrm{L}^{-}$ & - & - & 一 & - & $1 \cdot 77$ \\
\hline $\begin{array}{l}\text { Forebrain wt } \\
\text { (mg) } \\
\text { Relative to } \mathrm{G}^{+} \mathrm{L}^{+} \\
\quad \text { value }(\%)\end{array}$ & $349 \pm 3 \cdot 1$ & $\begin{array}{l}338 \pm 7 \cdot 0 \\
-3\end{array}$ & $\begin{array}{l}3 \circ 5 \pm 8 \cdot 4 \\
-13\end{array}$ & $\begin{array}{l}294 \pm 2 \cdot 8 \\
-16\end{array}$ & $\begin{array}{l}328 \pm 6 \cdot 7 \\
-6\end{array}$ \\
\hline $\begin{array}{l}\text { Value different ( } t \text { ) from } \\
\text { that of group: }\end{array}$ & & & & & \\
\hline $\mathrm{G}^{+} \mathrm{L}^{+}$ & - & I. 43 & $4 \cdot 87^{* * *}$ & I3.26** & $2 \cdot 84^{*}$ \\
\hline $\mathrm{G}^{+} \mathrm{L}^{-}$ & - & - & $2 \cdot 99^{* *}$ & $5 * 74^{* *}$ & $\mathrm{I} \cdot 02$ \\
\hline $\mathrm{G}^{-} \mathbf{L}+$ & - & - & - & $I \cdot 2 I$ & $2 \cdot 09^{*}$ \\
\hline $\mathrm{G}^{-\mathrm{L}^{-}}$ & 一 & - & - & 一 & $3 \cdot I^{* * *}$ \\
\hline \multicolumn{6}{|l|}{ Cerebellum wt } \\
\hline Relative to $\mathrm{G}^{+} \mathrm{L}^{+}$value $(\%)$ & - & -9 & $-\mathrm{I}_{5}$ & -20 & -14 \\
\hline $\begin{array}{l}\text { Value different }(t) \text { from } \\
\text { that for group: }\end{array}$ & & & & & \\
\hline $\mathrm{G}^{+} \mathrm{L}^{+}$ & 一 & $2 \cdot 23^{*}$ & $3.41 * *$ & $5 \cdot 17^{* * *}$ & $3 \cdot 36 * *$ \\
\hline $\mathrm{G}+\mathrm{L}^{-}$ & 一 & - & $2 \cdot 12^{*}$ & $5 * 48 * *$ & $2 \cdot 05^{*}$ \\
\hline $\mathrm{G}^{-} \mathrm{L}^{+}$ & - & 一 & - & $2 \cdot 08 *$ & 0.18 \\
\hline $\mathrm{G}^{-} \mathrm{L}^{-}$ & - & - & - & - & $2 \cdot 46^{*}$ \\
\hline
\end{tabular}

$\mathrm{G}^{+}$, well-nourished during gestation; $\mathrm{G}^{-}$, malnourished during gestation; $\mathrm{L}^{+}$, well-nourished during lactation; $\mathrm{L}^{-}$, malnourished during lactation; 20's, well-nourished, twenty pups/litter.

${ }^{*} P<0.05$, ** $P<0.01$; with 8 df $P=0.05$, when $t=\mathrm{r} .86 ; P=0.01$, when $t=2.89$, by onetailed tests.

$\dagger$ For details, see p. 374 .

that those sucking from a well-fed mother grew faster and were significantly heavier within a few days of birth (Fig. I).

Postnatal deprivation by sucking from a mother fed on the low-protein diet led to marked physical stunting even at $5 \mathrm{~d}$ old but had no discernible effects on reflex ontogeny until the $\mathrm{I}_{4}$ th day. Undernutrition by rearing in large litters was much more severe. Stunting was more pronounced and delays in the appearance of developmental markers began at $7-9 \mathrm{~d}$ of age. We could find no behavioural characteristics maturing between I 4 and $21 \mathrm{~d}$, the period when effects of postnatal malnutrition were most marked.

As each behavioural characteristic developed over several days, the analysis in Table 3 was carried out when the Kolmogorov-Smirnov test was most sensitive to differences between the control and experimental groups. That is, when most of the $\mathrm{G}^{+} \mathrm{L}+$ mice scored in the middle range of the $0-4$ development scale (see Experimental section), and the scores for all groups were most widely spread. This method 
Table 8. Effects of different pre- and postnatal feeding regimens on DNA content in forebrain and cerebellum of mice at $80 d$ of age

(Mean values with their standard errors, where given, for five mice/group)

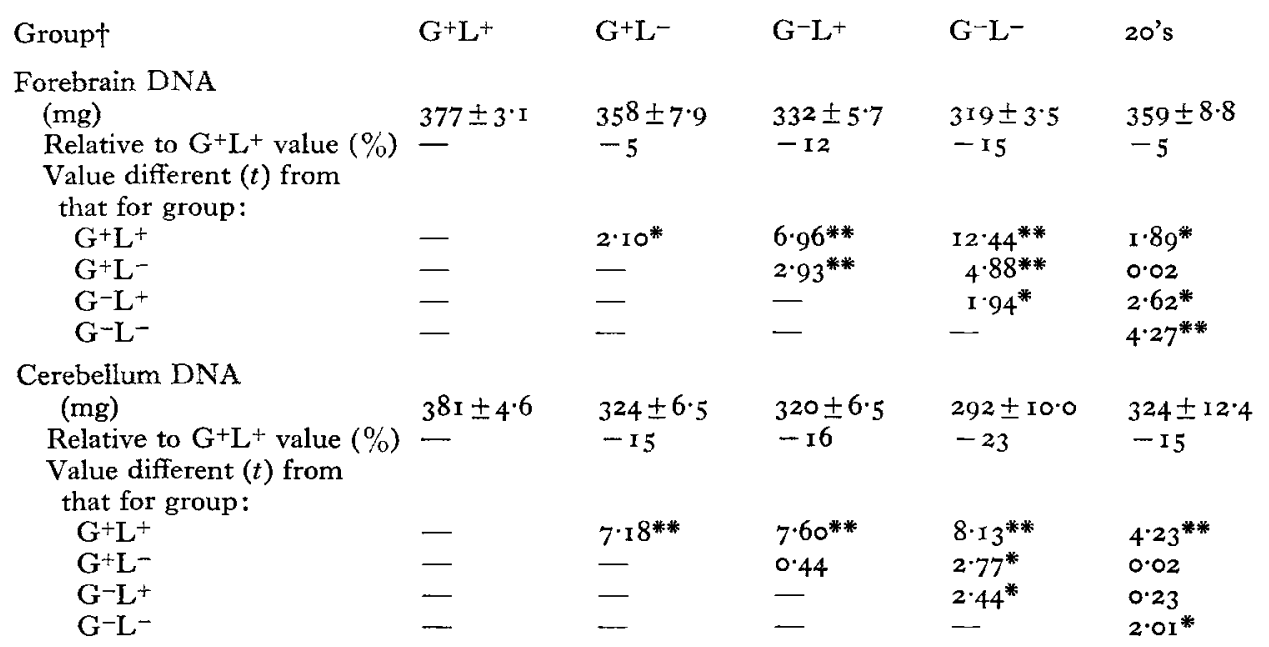

$\mathrm{G}^{+}$, well-nourished during gestation; $\mathrm{G}^{-}$, malnourished during gestation; $\mathrm{L}^{+}$, well-nourished during lactation; $L^{-}$, malnourished during lactation; 20's, well-nourished twenty pups/litter.

Difference between mean values was statistically significant: $* P<0.05$, ** $P<0.01$; by onetailed tests.

$\dagger$ For details, see p. 374 .

of analysis could obscure differences between the retarded groups, particularly between $\mathrm{G}^{-} \mathrm{L}^{+}$and $\mathrm{G}-\mathrm{L}-$, and accordingly all possible comparisons were made over the whole period of development for each physical and behavioural characteristic. These analyses did not reveal other significant differences between any of the groups.

The physical consequences of perinatal undernutrition may perhaps most profitably be analysed on the basis of the vulnerable period hypothesis. In its simplest form this hypothesis states: "If a developmental process be restricted by any agency at the time of its fastest rate, not only will this delay the process, but will restrict its ultimate extent, even when the restricting influence is removed and the fullest possible rehabilitation obtained' (Dobbing, 1968).

Our results confirm the predictions of this hypothesis in almost all respects. Peak growth rate of the mouse brain occurs between the $5^{\text {th }}$ and ${ }_{1} 5^{\text {th }}$ days after birth and undernutrition during this period produced marked reductions in body-weight, brain weight and brain cell number (see Tables 7 and 8 ). Undernutrition after weaning had no effect on the final body-weight or brain weight. The growth patterns and eventual physical deficiencies of the prenatally deprived mice $\left(\mathrm{G}^{-} \mathrm{L}^{+}\right)$, however, did not fit the hypothesis as well. During the period of the brain growth spurt they grew faster than both postnatally undernourished groups, in fact, their growth rate was almost the same as that of the control group (Fig. I). However, their ultimate bodyweight, brain weight and brain cell number were all below those of the mice subjected to postnatal undernutrition alone (Tables 7 and 8). The most likely explanation for this 
finding is that vulnerability is not limited simply to the peaks of each developmental process but is a continuous state from organogenesis until at least the peak of the growth spurt.

Simonson, Stephan, Hanson \& Chow (1971) and Smart et al. (1973) showed that prenatal growth restriction does influence subsequent adult behaviour in the rat. The present investigation shows that the mouse is also affected. Again, prenatal restriction $\left(\mathrm{G}^{-} \mathrm{L}^{+}\right)$had more effect than postnatal restriction $\left(\mathrm{G}^{+} \mathrm{L}^{-}\right)$but this time the effects were not additive (i.e. the $\mathrm{G}^{-} \mathrm{L}^{-}$and $\mathrm{G}^{-} \mathrm{L}^{+}$mice reached similar levels of avoidance performance). The 20 's produced by a long way the poorest performance, tending to confirm suggestions (Rajalakshmi \& Ramakrishnan, I972; Leathwood et al. 1974) that the behavioural effects of rearing in large litters arise from a combination of nutritional and social factors.

In this study, the early handling involved in the developmental study had no significant influence on avoidance behaviour. However, the consistent, but slight, improvement it did produce justifies further investigation of the relationship between early nutritional deprivation and early handling.

We would like to thank Mlle C. Berent for doing the DNA analyses, Mme A. Bise for technical assistance, and Professor J. Mauron and Dr J. Dobbing for their useful comments during the preparation of this manuscript.

\section{REFERENCES}

Blackwell, B.-N., Blackwell, R. Q., Yu, T. T. S., Weng, Y. \& Chow, B. F. (I969). F. Nutr. $97,79$.

Bovet, D., Bovet-Nitti, F. \& Oliverio, A. (I968). Brain Res. Io, I68.

Cowley, J. J. \& Griesel, R. D. (I966). Anim. Behav. 14, 506.

Dobbing, J. (I968). In Applied Neurochemistry p. 287 [A. N. Davison and J. Dobbing, editors]. Oxford: Blackwell.

Fox, W. M. (1965). Anim. Behav. 13, 234.

Hawk, P. B. \& Oser, B. (r93 I). Science, N.Y. 74, 369.

Lát, J., Widdowson, E. M. \& McCance, R. A. (I960). Proc. R. Soc. B I53, 347.

Leathwood, P. D., Bush, M. S., Berent, C. D. \& Mauron, J. (1974). Life Sci. 14, I57.

Levine, S. \& Mullins, R. F. (1966). Science, N.Y. 152, I 585.

Levitsky, D. A. \& Barnes, R. H. (1970). Nature, Lond. 225, 468.

Margolis, F. L. (I969). F. Neurochem. r6, 447.

Mauron, J. \& Mottu, F. (1962). F. agric. Fd Chem. ro, 5 I2.

Rajalakshmi, R. \& Ramakrishnan, C. V. (1972). Wld Rev. Nutr. Diet. I5, 35.

Seitz, P. F. D. (1954). Am. F. Psychiat. 1 10, 916.

Siegel, S. (1956). Nonparametric Statistics for the Behavioural Sciences. New York: McGraw-Hill.

Simonson, M., Sherwin, R. W., Anilane, J. K., Yu, W. Y. \& Chow, B. F. (rg68).F. Nutr. 98, i8.

Simonson, M., Stephan, J. K., Hanson, H. M. \& Chow, B. F. (I 97 I). F. Nutr. Ior, 33 I.

Smart, J. L. \& Dobbing, J. (1971 a). Brain Res. 28, 85.

Smart, J. L. \& Dobbing, J. (r97 r b). Brain Res. 33, 303.

Smart, J. L., Dobbing, J., Adlard, B. P. F., Lynch, A. \& Sands, J. (1973). F. Nutr. 103, I327.

Widdowson, E. M. \& McCance, R. A. (1963). Proc. R. Soc. B I58, 329.

Winick, M. (1970). Fedn Proc. Fedn Am. Socs exp. Biol. 29, I 510. 